\section{ECONOMICS}

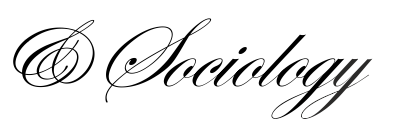

Rajnoha, R., Lesníková, P., \& Vahančík, J. (2021). Sustainable economic development: The relation between economic growth and quality of life in V4 and Austria. Economics and Sociology, 14(3), 341-357. doi:10.14254/2071789X.2021/14-3/18

\title{
SUSTAINABLE ECONOMIC DEVELOPMENT: THE RELATION BETWEEN ECONOMIC GROWTH AND QUALITY OF LIFE IN V4 AND AUSTRIA
}

\author{
Rastislav Rajnoha \\ Tomas Bata University in Zlin, \\ Zlin, Czech Republic \\ E-mail:rajnoha@utb.cr. \\ ORCID 0000-0002-9332-9926 \\ Petra Lesníková \\ Technical University in Zvolen, \\ Zvolen, Slovak Republic \\ E-mail:Lesnikova@tusvo.sk. \\ ORCID 0000-0001-9977-0811
}

Jozef Vahančík

Pan-European University,

Bratislava, Slovak Republic

E-mail:jozef@vahancik.com

Received: January, 2021

1st Revision: July, 2021

Accepted: August, 2021

DOI: $10.14254 / 2071-$

789X.2021/14-3/18

JEL Classification: O11, O44, Q01, Q56
ABSTRACT. The future belongs to sustainability. It is becoming more important to achieve sustainable economic development. Therefore, in addition to the countries' economic performance, the continuous improvement of the quality of life should also be essential. The set topic is crucial, even necessary to achieve the ambitious goals of today's society in terms of sustainable economic development. The need for solution highlights the possible changes in the social aspect of economic development. Following this challenge, the objective of the paper is to evaluate the development of 26 quality of life indicators from selected 6 categories in the V4 countries and Austria as a research benchmark country between 2010-2019 and to identify the impact of the level of GDP on these indicators. The descriptive statistics and linear regression analysis are used. Most life quality indicators reveal that the level of the V4 countries is better than the EU 27 average or the same. In conclusion, $61.5 \%$ of variables in all countries related to research hypothesis was confirmed, which means that the GDP growth had a positive effect on the improvement of the quality of life within these variables. However, comparing to Austria as a highly developed country, a significant sustainable development gap can be still observed in V4.

Keywords: economic growth, social performance, quality of life, sustainable economic development, V4, Austria, linear regression analysis

\section{Introduction}

Currently, in the context of sustainability, the social aspect of development should not be separated from economic development of any country. In general, the ranking of countries by gross domestic product (GDP) is a useful way of analyzing the size of the world's economy and thus of identifying direction trends and performance patterns of a country's economy (IMD World Competitiveness Center). The innovation (including R\&D) could be the main driver of economic growth and competitiveness (Kiseláková et al., 2018; Juřričková et al., 2019). Competitiveness means the attributes and qualities of an economy that allow a more efficient use of factors of production (Schwab, 2019). However, many of indices (Human development index, Global competitiveness index, Environmental performance index, etc.) or 
traditionally used indicator of GDP are not able to offer a holistic image of the performance and sustainable economic development of countries (Popescu et al., 2017; Uslu et al., 2020; Vovk et al., 2017).

According to our opinion as a basic motivation of our research, it is possible and even vitally necessary to think about sustainable economic development in the way of how it promotes the well-being of inhabitants. Based on this, the objective of the paper is to evaluate the development of the selected indicators of quality of life in the chosen central Europe countries, and to identify the impact of the level of GDP on analyzed indicators in these countries, especially comparing their development in the V4 group (Czech Republic, Hungary, Poland, and Slovakia) with Austria as a benchmark of a highly developed Central European (CE) country. We consider the study of the given topic to be important, even necessary to achieve the ambitious goals of today's society in terms of sustainable economic development.

Based on the above mentioned, it is evident that the issue of sustainable economic development and quality of life are increasingly actual. New knowledge of the interrelationship between these fields can bring a new view on the economic and social trends. Therefore, a closer examination of interconnections is needed. Moreover, these topics are interrelated and intersectingly current world issues, from decent work, through education quality, gender equality, no poverty, to good health and wellbeing. An essential factor is the level of GDP, which can affect several aspects of quality of life. This is a research gap and the reason why we set out the assumption of main research hypothesis and additional research question (see Chapter 1 below). The paper is structured as follows. The theoretical review is included in chapter 1 in conjunction with research hypothesis and research question. The main objective, data and methodology used are described in chapter 2. The results section (chapter 3) provides a comprehensive summary of the most important results leading to a discussion and evaluation of the results with previous research works of other authors worldwide.

\section{Literature review}

It can be said that a more competitive country is likely to grow economically faster than others. Productivity leads to growth, which can cause the growth of income and improvement of well-being (Cann, 2017): "Another way to think about what makes a country competitive is to consider how it actually promotes our well-being. A competitive economy, we believe, is a productive one. And productivity leads to growth, which leads to income levels and hopefully, at the risk of sounding simplistic, improved well-being".

The current competition in world markets is very intense. This is causing national economies and businesses to strive in order to improve their competitiveness position. However, an important but rather worrying recent finding on economic growth, competitiveness or productivity is that "a country's relative position depends almost entirely on the chosen method and indicators" (Miola \& Schiltz, 2019).

In relation to GDP, this presents a powerful and widely accepted indicator that monitors mainly short-term economic activity with its fluctuations. It represents a key indicator of assessing the country's economic growth (Ivanová \& Masárová, 2018). On the other hand, there is some criticism about the indicator due to the absence of presentation of social and environmental aspects, e.g., health care, education, environment, etc. (Stiglitz et al., 2009). The problem with GDP is that, as an individual indicator, it does not provide sufficient information about well-being of the citizens of Europe; and difficulties with the most suitable measurement of economic output in accordance with modern society and its progress still exist (European Commission, 2009; Puglisi \& Şerban, 2019, p. 29). The GDP should be supplemented by topics such as climate change or other environmental and social problems 
(European Commission, 2009). Furthermore, the methodology for calculating GDP needs to be improved (Grishin et al., 2019). On the other hand, GDP per capita still belongs to the mostly used output indicators in many of areas, as well as in the case of quality of life, e.g., the relationship between CO2 emissions and GDP per capita, and between health spending and economic growth (Chaabouni \& Saidi, 2017); impact of increased spending on education on GDP per capita in developing countries, whereas education affects this economic output in positive way (Appiah, 2017). There is an increasing need in society to look at GDP from a slightly different perspective. It is about multi-target scenarios in relation to sustainability targets mainly in climate and resources areas or trying to build a new approach in quantifying the ecological and environmental degradation cost (Svenfelt et al., 2019; Stjepanović et al., 2017). Moreover, nowadays, there is a great interest of broader welfare measurements consisting of more aspects of economic output and well-being (Kalimeris et al., 2020; Ranasinghe \& Pradeepamali, 2019).

Hammer and Pivo (2016, p. 7) perceive sustainable economic development as "the purpose of economic development to improve well-being and quality of life through the creation of jobs and wealth, and the process of economic development to include creation, expansion, retention, and recruitment, of jobs and businesses through a mix of techniques". According to Androniceanu et al. (2018) it is naturally, if a country is successively gaining economic growth, we would expect that country to significantly improve the quality of life for the citizens. The results of this recent research study conducted in Romania demonstrated high economic growth, but without the improvement of quality of life.

From the research and academic points of view, some research works have only recently been analyzed focusing on this topic in EU countries (Čepel, 2019; Gavurová et al., 2020). It exists an effort to make a proposal to use a novel composite index of quality of life to rank EU countries (Maricic, 2019). Recently, it has been found out that the inhabitants of wealthier countries living in relatively high-quality conditions, do not have a lower level of subjective well-being in comparison to inhabitants living in the Eastern European countries (Kwarciński \& Ulman, 2020). According to Stavytskyy et al. on the issue of gender gap and its mitigation (mainly the Global Gender Gap Index) is influenced not only by economic factors, e.g., an increase in GDP per capita, a decrease in unemployment, etc. (Stavytskyy et al., 2020). Within the analyses of GDP and well-being, the Portuguese GDP alone hardly has any impact on the well-being index. The GDP per capita has a positive effect on this field (Ribeiro, Santos, 2019, p. 209).

Several recent research studies in this field have also been carried out worldwide. In case of Indonesia, the infrastructure positively affects the economic growth. Another finding showed that economic growth promotes income equality, whereby it is a positive phenomenon (Nugraha et al., 2020). The study of Roka (2019) conducted in China and South Asian countries analyses the relation between GDP growth and Income on happiness and shows the negative association between GDP growth and happiness. The government of each country should invest in education (especially in higher education), $R \& D$, and innovation. They should invest in their inhabitants mainly in health and education to be able to compete in future (Ekici et al., 2019; Quiñonez Tapia at al., 2020; Caballero et al., 2020). According to Caballero et al. (2020) for emerging economies, the implementation of Education 4.0 is an essential asset for future economic and social development in Latin American economies. Recent research study realized by Chisadza and Loots (2019) analyses the economic growth performance in Africa between 1960 and 2016 and its effect on various quality of life indicators. The study highlighted that the economic growth was not inclusive, as it failed to contribute to the improvement in the quality of life of its citizens. According to an extensive research realized by Kim (2017) in 222 countries worldwide, the knowledge-based economy supports economic growth and is significant in enhancing not only economic growth but also 
quality of life across the world. Moreover, the opposite relationship was examined in recent research study provided by Fan et al. (2016) suggesting that human capital and quality of life indicators significantly contribute to economic growth in the USA.

In relation to the crucial issue of sustainability, some studies have also been carried out. The association between state PM2.5 levels and average life expectancy is analyzed by Hill et al. (2019), whereby particulate matter is especially detrimental to life expectancy in US states with higher levels of income inequality. According to evidence from Indonesia (Elistia \& Syahzuni, 2018), it is evident that there is a causal relationship between economic growth and human development index which reveal that country's development relates to the influence of GDP per capita. The study of Giacalone et al. (2018, p. 134) and its results confirmed the fact that "surely a certain dimension of sustainability impacts GDP on different mechanisms and this is an undeniable fact”.

Based on above mentioned and despite criticism of the GDP, we consider this indicator to be applicable for our research as the main economic output of a country and we set a research hypothesis: the higher overall economic performance of the country has a positive effect on the living standards of the country and its inhabitants measured by quality of life indicators. Previously, it was necessary to answer the research question: Does each of the V4 countries achieve values of quality of life indicators such as the EU average?

\section{Methodology and data set}

V4 is a dynamic regional group of EU member states, whereby each of them shows typical features of supporting competitiveness and economic growth. The V4 countries are interconnected within their history, geographical location, and values. Within this group the space is created to strengthen coordination mechanism to find common positions in terms of the current issues of foreign and European policy, regional development, and economic cooperation. The cooperation between these countries played an important role in the past in relation to transition from a totalitarian regime to a democratic society (since 1989). At the same time, these countries represent, after the countries of Western Europe, the potential for raising living standards as well as gradually meeting the goals of sustainable development. Additionally, due to former long-term historical co-development (to 1918) we decided to add Austria as a highly economic developed CE country as an immediate benchmark in the research. Whereas, according to Androniceanu et al. (2018), the economic growth and quality of life are two essential topics to make a time-based analysis of the evolution of a state or a comparison with other states.

Sustainable economic development is represented by goals with a wide range of areas. Most of these goals and its indicators largely overlap in terms of content with life quality indicators. Relevant statistics are presented in many dimensions of life quality in the EU, which can be measured statistically to represent the different complementary aspects of life quality (ec.europa.eu, a). The data about all analyzed life quality indicators in selected countries were obtained from database of Eurostat (ec.europa.eu, a). The object of analysis were 10 years - from 2010 to 2019 (data for 2020 were not yet available). According to Eurostat, the data of life quality are fragmented to 9 categories. The selected life quality indicators (in total 26 indicators were selected) were divided into 6 most important life quality agenda research categories according to the related content which are presented in Table 1. 
Table 1. Overview of the quality of life indicators in individual categories included in research framework

\section{Economic oriented indicators}

[1] Median equivalized net income (PPS)

[2] At-risk-of-poverty rate $(\%)$

[3] Inability to make ends need (\%)

[4] Total population living in a dwelling with a leaking roof, damp walls, floors or foundation, or rot in window frames or floor $(\%)$

[5] Inability to face unexpected financial expenses $(\%)$

[6] Arrears (mortgage or rent, utility bills or hire purchase) $(\%)$

[7] Recorded offences - theft (per hundred thousand inhabitants)

[8] Crime/violence/vandalism in the area (\%)

\section{Health oriented indicators}

[16] Life expectancy (per years)

[17] Healthy life years (per years)

[18] Self-perceived health (\%)

[19] Self-reported unmet needs for medical examination $(\%)$

\section{Gender equality-oriented indicators}

[23] Gender employment gap (\% of total population)

[24] Gender pay gap (\%)

\section{Employment oriented indicators}

[9] Unemployment rates (\%)

[10] Long-term unemployment (\% of active population)

[11] People living in households with very low work intensity ( $\%$ of total population)

[12] Average number of usual weekly hours of work in main job (hours)

[13] Employed persons working on Saturdays as

a percentage of the total employment (\%)

[14] Employed persons working on Sundays as a

percentage of the total employment (\%)

[15] Inactive population as a percentage of the total population $(\%)$

\section{Education oriented indicators}

[20] Population by educational attainment level - upper secondary $(\%)$

[21] Population by educational attainment level - tertiary $(\%)$ [22] Participation rate in education/training (\%)

\section{Natural and living oriented indicators}

[25] Exposure to air pollution by particulate matter (particulates $<2.5 \mu \mathrm{g} / \mathrm{m}^{3}$ )

[26] Pollution, grime, or other environmental problems $(\%)$

Source: own compilation

The indicator of GDP per capita in purchasing power parity (PPS) is used due to its nature being one of the most basic indicators of overall economic development and the overall standard of living of the country's population and its suitability in international comparisons. The data about the GDP value were obtained from Eurostat (ec.eurostat.eu, b).

Adequate method to verify the set research hypothesis was linear regression analysis. This analysis expresses the relationship between two variables and estimates the value of the dependent variable (y) based on a selected value of the independent variable (x) through the regression equation. $\beta_{0}$ represents a parameter of model, so-called locating constant that expresses the value of the dependent variable (y) if the independent variable $(\mathrm{x})$ is $0 . \beta_{1}$ is a parameter of model that indicates how many units $\mathrm{Y}$ changes on average if $\mathrm{X}$ changes by 1 unit (Mason \& Lind, 1990):

$$
y=\beta_{0}+\beta_{1} \mathrm{x}
$$

For better understanding of our research, the variable $\mathrm{X}$ represents analyzed indicators of life quality, variable $\mathrm{Y}$ means the GDP value, $\beta_{0}$ and $\beta_{1}$ are the parameters of model, whereas the $\beta_{0}$ is locating constant and according to $\beta_{1}$, it is possible to determine whether it is a positive or negative linear dependence.

For assessing the relationship strength between analyzed variables the correlation (Pearson's) coefficient (r) was used. Collected data for this study were processed by software 
STATISTICA 12 using .05 p-level of significance. The descriptive statistics was used to answer the research question.

\section{Results of study}

According to the objective of research, this section brings the main study results. At first, it was necessary to answer the research question: Do the individual V4 countries achieve values of life quality indicators such as the EU average? The life quality indicators were divided into 6 main categories mentioned in Table 1. We analyzed the data of selected indicators of each country of the year 2019.

The field of economic oriented indicators (left side) and employment-oriented indicators (right side) is shown in Graph 1 (except the median net income, recorded offences of theft and average number of weekly hours of work in main job - due to the different units).

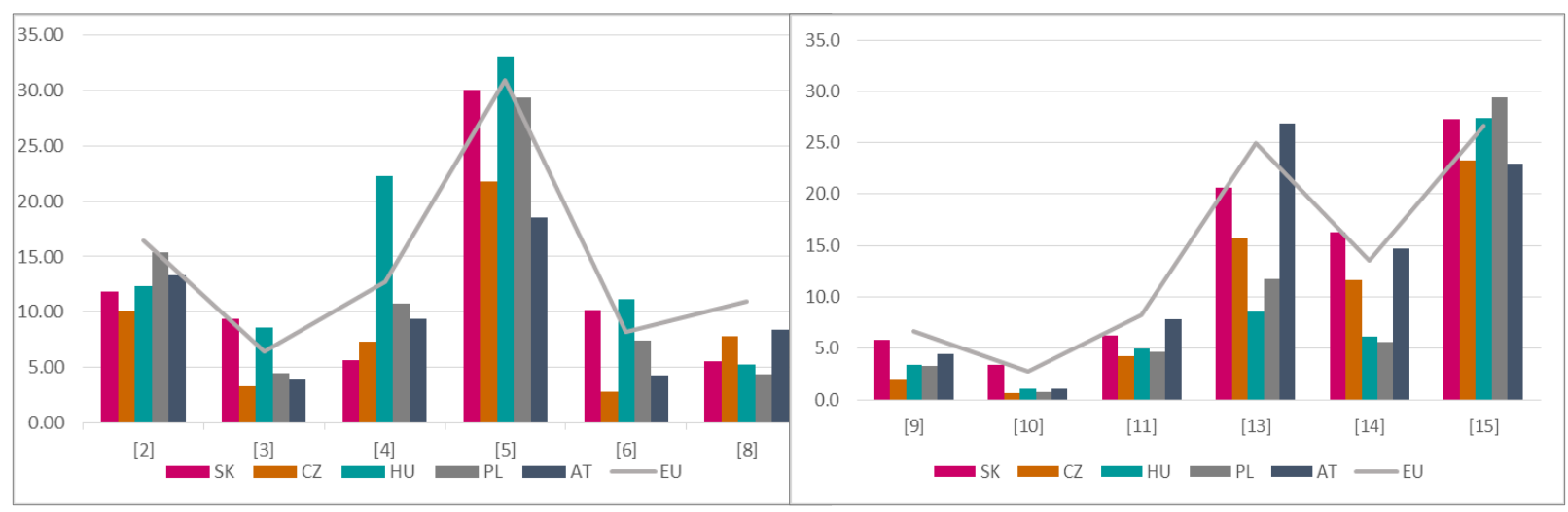

Graph 1. Economic and employment-oriented indicators in V4 countries, Austria, and EU 27 Source: own processing according to Eurostat

Disposable household income includes all income from work (employees' wages and self-employment earnings), private income from investment and property, transfers between households, all social transfers received in cash including old-age pensions. To consider the impact of differences in household size and composition, the total disposable household income is "equivalized" (ec.europa.eu, d). The level of median net income in V4 countries (11,558 in PPS) is still significantly under the level of EU 27 (17,422 in PPS), however it has a growing tendency. The most recorded offences in relation to theft (in per hundred thousand inhabitants) in V4 was recorded in Hungary (656) and the fewest in Poland (260). In Austria, as a more developed country, this indicator was higher, which is surprising $(1,276)$. In each country the offences have a declining character (with the slight fluctuations). The average value of this indicator of EU countries was not available (eurostat.eu, a). In comparison to the EU 27, the V4 countries achieve a better average value than the EU average in terms of crime, violence, or vandalism and at-risk-of-poverty rate indicator. The same value is in the case of the inability to unmet needs indicator (households making ends meet with great difficulty); and other indicators achieved a slightly better value. Looking at the V4 structure itself, the Czech Republic achieves better value of almost all indicators (apart from crime, violence, or vandalism - the highest value is in Austria, but it is still under the EU average). In comparison to the V4 countries, Austria achieved a better result (it means a lower value) in indicator of inability to face unexpected financial expenditures, as well as within other indicators [see indicators 3-6 in Table 1]. Austria reaches better values in all indicators even in comparison to the average of EU 27. 
In the case of the employment-oriented indicators the situation is similar (Graph 1). Indicator of average number of usual weekly hours of work and its higher value has the negative character in connection with the quality of life. In all V4 countries its value represented over 40 hours per week except Hungary (39.5), whereby the EU 27 average is 37.1 hours. The value of inactive population indicator is at the level of the EU average $(26 \%)$. The value of other indicators of V4 countries is better than EU 27. The Slovak Republic reports a slightly negative character in almost all indicators, whereby the best values are achieved in the Czech Republic. Compared to the V4 average, Austria shows a better value in case of long-term unemployment rate and average number of weekly hours in work. However, Austria reaches a relatively high value in the indicator of employed persons working on Saturdays (26.9\% of the total employment) representing even more than the EU average $(25 \%)$.

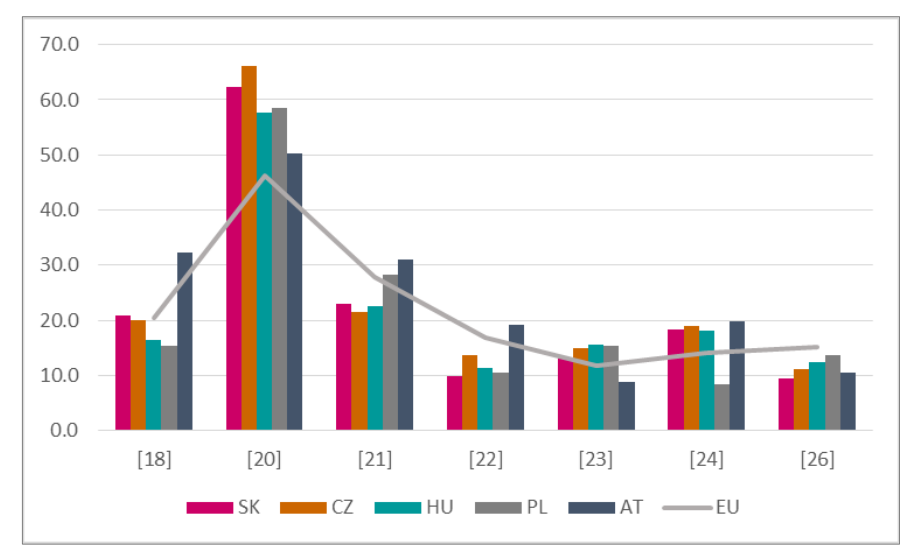

Graph 2. Health, education, gender, pollution indicators in V4, Austria, and EU 27 Source: own processing according to Eurostat

Graph 2 illustrates other 4 categories of indicators without life expectancy, healthy life years, self-reported unmet needs for medical examination, and air pollution indicator (due to the different units, or the value of indicator is too low to be shown in the graph). Almost all health-oriented indicators within the V4 countries are below the EU 27 average (three of them are not shown in Graph 2). Indicator of life expectancy is not available for 2019. The longest life expectancy in V4 countries is recorded in the Czech Republic (79.1 years), while longer life expectancy is in Austria (almost 82 years) and EU countries (81 years). The healthy life years level is also lower than in the EU (level 64.6 years). Surprisingly, the level of this indicator is lower in Austria (57.3 years). The indicator of self-reported unmet needs for medical examination reaches $0.80 \%$ in the EU, while the situation is slightly better in the V4 countries $(0.45 \%)$. The average level of the indicator of self-perceived health in V4 achieved a lower level $(18.2 \%)$ than the EU average $(20.5 \%)$. The lowest value $(15.4 \%)$ is reached in Poland and the highest $(20.8 \%)$ is in the Slovak Republic. As far as indicators from the field of education, the only indicator of population by upper secondary education is in the V4 countries at a higher level (average 61.1\%) than in the EU (46.3\%). On the contrary, in the case of tertiary education the situation is different, whereby only Poland (28.2\%) and Austria (31.1\%) reach higher value than the EU 27 average (27.9\%). The same situation is in the case of the indicator of participation rate on education and training (EU $27=16.8 \%$; V4 $=11.4 \%$ ).

Gender gap indicators in V4 countries is above the EU 27 average (which means a negative situation). Within the EU 27, the gender employment gap is at the level of $11.7 \%$, while in the V4 it is about $3 \%$ more (the largest gap is in Hungary; the smallest gap is in the Slovak Republic). In Austria situation with this indicator is better (only 8.8\%). In the case of 
the gender pay gap indicator only Poland (8.5\%) is under the EU 27 average (14.1\%). From the environmental field, we analyzed two indicators. The average value of V4 in pollution, grime and other environmental problems indicator reach a better value (11.7\%) than in the EU $27(15.1 \%)$. Exposure to air pollution measured in particulates of less than 2.5 micrometers in V4 countries is at the value of $15.5 \%$ (the lowest value is reached in the Slovak Republic), the EU 27 average shows the value of $12.6 \%$. This indicator measures the population weighted annual mean concentration of particulate matter in urban background stations in agglomerations. Fine and coarse particulates (PM10), i.e., particulates whose diameters are less than 10 micrometers, can be carried deep into the lungs where they can cause inflammation and exacerbate the condition of people suffering from heart and lung diseases. Fine particulates (PM2.5) are those whose diameters are less than 2.5 micrometers. They are, therefore, a subset of the PM10 particles. Their deleterious health impacts are more serious than PM10 as they can be drawn further into the lungs and may be more toxic (ec.europa.eu, c).

\subsection{Results of linear regression analysis}

In the Section 1 we set the research hypothesis related to the relationship between economic performance of a country and life quality indicators in V4 countries and Austria. Before testing the main research hypothesis, we introduced a brief view of the trend of GDP in each analyzed country (Graph 3).

From Graph 3 it is evident that the value of GDP (in PPS per capita) in Austria is still (more than 30 years after change of political regime in V4) much higher than in the V4 countries. In all countries (except Slovakia in 2015/2016) the trend is growing. Among the V4 countries, the Czech Republic has the highest value of GDP, the lowest economic performance is achieved by Poland, but currently by Slovakia (in 2019). At present, due to the coronavirus pandemic, the most significant drop in economic output for both the euro area and the EU 27 is recorded, but the results of each country have not been published yet (European Central Bank, 2021).

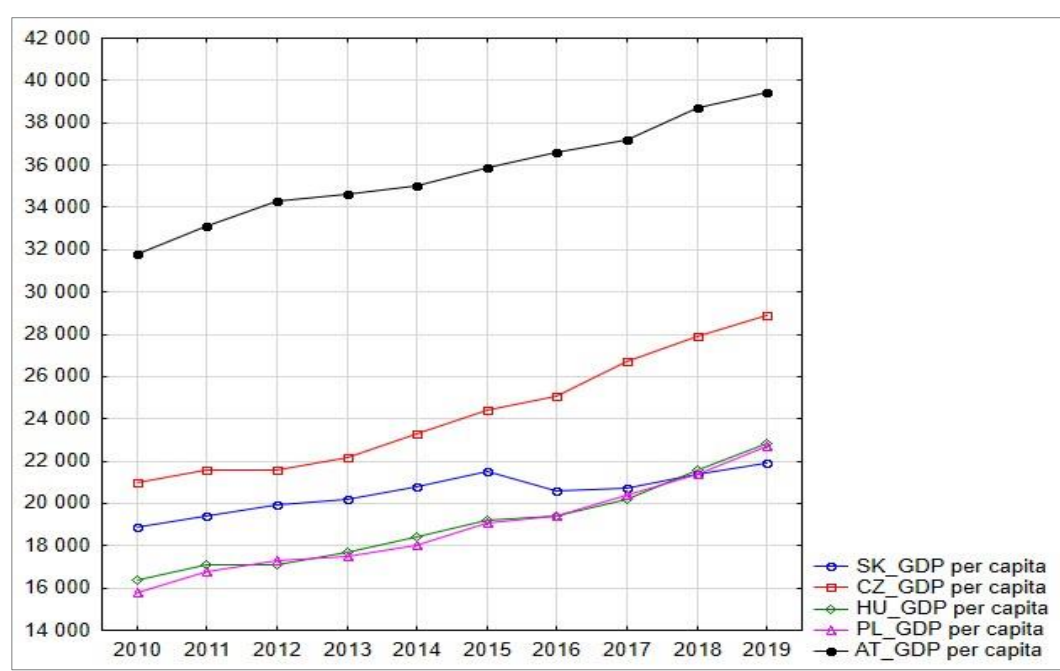

Graph 3. Trend of GDP in V4 countries and Austria

Source: own processing according to Eurostat

The results of linear regression analysis are shown in Tables 2-7. As we mentioned in the Section 2, these indicators are divided into 6 research categories. 
Table 2. Economic indicators

\begin{tabular}{|c|c|c|c|c|c|c|c|c|c|c|}
\hline Indicators & SI & & C & & PI & & & & AT & \\
\hline & $\begin{array}{c}\mathrm{p} \text {-level } \\
\beta_{0}\end{array}$ & $\begin{array}{c}\mathrm{r} \\
\beta_{1}\end{array}$ & $\begin{array}{c}\text { p-level } \\
\beta_{0}\end{array}$ & $\begin{array}{c}\mathrm{r} \\
\beta_{1}\end{array}$ & $\begin{array}{c}\mathrm{p} \text {-level } \\
\beta_{0}\end{array}$ & $\begin{array}{l}\mathrm{r} \\
\beta_{1}\end{array}$ & $\begin{array}{c}\text { p-level } \\
\beta_{0}\end{array}$ & $\begin{array}{c}\mathrm{r} \\
\beta_{1}\end{array}$ & $\begin{array}{c}\mathrm{p} \text {-level } \\
\beta_{0}\end{array}$ & $\begin{array}{c}\mathrm{r} \\
\beta_{1}\end{array}$ \\
\hline $\begin{array}{l}\text { Median net } \\
\text { income }\end{array}$ & $\begin{array}{c}. \mathbf{0 0 3} \\
-2157.0\end{array}$ & $\begin{array}{c}.84 \\
.57779\end{array}$ & $\begin{array}{c}.000 \\
-918.5\end{array}$ & $\begin{array}{c}.99 \\
.51549\end{array}$ & $\begin{array}{c}.000 \\
-3131.8\end{array}$ & $\begin{array}{c}.98 \\
.69168\end{array}$ & $\begin{array}{c}.000 \\
952.4\end{array}$ & $\begin{array}{c}.97 \\
.36461\end{array}$ & $\begin{array}{c}. \mathbf{0 0 0} \\
1047.7\end{array}$ & $\begin{array}{c}.96 \\
.58311\end{array}$ \\
\hline $\begin{array}{l}\text { At-risk-of- } \\
\text { poverty rate } *\end{array}$ & $\begin{array}{l}.005 \\
21.7\end{array}$ & $\begin{array}{c}-.91 \\
-.0004\end{array}$ & $\begin{array}{l}.959 \\
9.4\end{array}$ & $\begin{array}{c}.02 \\
.0000\end{array}$ & $\begin{array}{l}.013 \\
27.6\end{array}$ & $\begin{array}{c}-.82 \\
-.0006\end{array}$ & $\begin{array}{l}.065 \\
21.1\end{array}$ & $\begin{array}{l}-.78 \\
-.0004\end{array}$ & $\begin{array}{l}.489 \\
15.5\end{array}$ & $\begin{array}{c}-.29 \\
-.0000\end{array}$ \\
\hline $\begin{array}{l}\text { Inability to } \\
\text { make ends need }\end{array}$ & $\begin{array}{l}.289 \\
24.7\end{array}$ & $\begin{array}{c}-.37 \\
-.0007\end{array}$ & $\begin{array}{l}.000 \\
23.4\end{array}$ & $\begin{array}{c}-.90 \\
-.0007\end{array}$ & $\begin{array}{l}.000 \\
39.0\end{array}$ & $\begin{array}{c}-.98 \\
-.0015\end{array}$ & $\begin{array}{l}.000 \\
79.1\end{array}$ & $\begin{array}{c}-.97 \\
-.0031\end{array}$ & $\begin{array}{l}.001 \\
14.5\end{array}$ & $\begin{array}{c}-.89 \\
-.0003\end{array}$ \\
\hline $\begin{array}{l}\text { Population } \\
\text { living in a } \\
\text { dwelling etc. }\end{array}$ & $\begin{array}{l}.171 \\
18.0\end{array}$ & $\begin{array}{c}-.47 \\
-.0006\end{array}$ & $\begin{array}{l}.000 \\
22.6\end{array}$ & $\begin{array}{c}-.93 \\
-.0005\end{array}$ & $\begin{array}{l}.460 \\
15.4\end{array}$ & $\begin{array}{c}-.26 \\
-.0002\end{array}$ & $\begin{array}{l}.350 \\
30.2\end{array}$ & $\begin{array}{c}-.33 \\
-.0003\end{array}$ & $\begin{array}{l}.002 \\
32.7\end{array}$ & $\begin{array}{c}-.84 \\
-.0006\end{array}$ \\
\hline $\begin{array}{l}\text { Inability to face } \\
\text { unexpected fin. } \\
\text { expenses }\end{array}$ & $\begin{array}{l}.082 \\
74.7\end{array}$ & $\begin{array}{c}-.58 \\
-.0019\end{array}$ & $\begin{array}{l}\mathbf{0 0 0} \\
97.2\end{array}$ & $\begin{array}{c}-.95 \\
-.0026\end{array}$ & $\begin{array}{c}\mathbf{. 0 0 0} \\
118.1\end{array}$ & $\begin{array}{c}-.95 \\
-.0040\end{array}$ & $\begin{array}{c}\mathbf{. 0 0 1} \\
219.9\end{array}$ & $\begin{array}{c}-.88 \\
-.0084\end{array}$ & $\begin{array}{l}.000 \\
49.1\end{array}$ & $\begin{array}{c}-.92 \\
-.0008\end{array}$ \\
\hline Arrears & $\begin{array}{l}.469 \\
17.2 \\
\end{array}$ & $\begin{array}{c}-.26 \\
-.0004 \\
\end{array}$ & $\begin{array}{l}\mathbf{. 0 0 0} \\
16.0 \\
\end{array}$ & $\begin{array}{c}-.96 \\
-.0005 \\
\end{array}$ & $\begin{array}{l}\mathbf{. 0 0 0} \\
38.3 \\
\end{array}$ & $\begin{array}{c}.94 \\
-.0014 \\
\end{array}$ & $\begin{array}{l}.000 \\
69.7 \\
\end{array}$ & $\begin{array}{c}-.94 \\
-.0026 \\
\end{array}$ & $\begin{array}{l}.000 \\
18.9 \\
\end{array}$ & $\begin{array}{c}.90 \\
-.0004 \\
\end{array}$ \\
\hline $\begin{array}{l}\text { Recorded } \\
\text { offences } * *\end{array}$ & $\begin{array}{c}.059 \\
3845.3\end{array}$ & $\begin{array}{c}-.74 \\
-.1655 \\
\end{array}$ & $\begin{array}{c}\mathbf{. 0 0 0} \\
3518.2 \\
\end{array}$ & $\begin{array}{c}-.97 \\
-.1086\end{array}$ & $\begin{array}{c}\mathbf{. 0 0 0} \\
2008.9\end{array}$ & $\begin{array}{c}-.96 \\
-.0841 \\
\end{array}$ & $\begin{array}{c}\mathbf{. 0 0 3} \\
4942.3 \\
\end{array}$ & $\begin{array}{c}.96 \\
-.0202 \\
\end{array}$ & $\begin{array}{c}\mathbf{0 0 4} \\
4848.0 \\
\end{array}$ & $\begin{array}{c}-.88 \\
-.0903 \\
\end{array}$ \\
\hline $\begin{array}{l}\text { Crime, } \\
\text { violence, or } \\
\text { vandalism } \\
\end{array}$ & $\begin{array}{l}.002 \\
43.5\end{array}$ & $\begin{array}{c}-.86 \\
-.0017\end{array}$ & $\begin{array}{l}.000 \\
35.4\end{array}$ & $\begin{array}{c}-.98 \\
-.0010\end{array}$ & $\begin{array}{l}.000 \\
12.0\end{array}$ & $\begin{array}{c}-.97 \\
-.0003\end{array}$ & $\begin{array}{l}.003 \\
32.9\end{array}$ & $\begin{array}{c}-.84 \\
-.0012\end{array}$ & $\begin{array}{l}.008 \\
30.4\end{array}$ & $\begin{array}{c}-.78 \\
-.0005\end{array}$ \\
\hline
\end{tabular}

Notes: *available data 2011-2019; **available data 2010-2018; data highlighted in bold indicate statistic dependence between variables

Source: own compilation

The positive character of the statistical dependence between analyzed variables has been confirmed in the case of the median net income. In the condition of Slovakia, it is possible to define (according to formula 1 mentioned above) the relationship between GDP and indicator of median net income through the regression function $y=-2,157+.57779 x$. From above mentioned it is evident, that with the improvement of the country's GDP by a thousand units in PPS, the median net income increases by 578 PPS on average. The correlation coefficient $(\mathrm{r}=.84)$ indicates a positive, strongly significant statistical dependence. Overall, with an increase of GDP by one thousand PPS units, this indicator increases in individual countries by 364.6 PPS units on average (the lowest value was recorded in Hungary) to 691.6 PPS units (the highest value was recorded in Poland). The correlation coefficient ( $r$ ) indicates a positive, strongly significant statistical dependence in the case of each country. Other indicators in this category recorded the negative statistical linear dependence, which is however, a positive oriented feature. While the GDP of a country is improved, value of these selected indicators is decreasing by several $\%$ on average, which means a positive development trend. When the country's GDP improves by one thousand PPS: the values of inability to make ends need decrease by $0.3 \%$ on average (AT) to by $1.5 \%$ (PL); inability to face unexpected financial expenses decrease by $0.8 \%$ on average (AT) to by $8.4 \%(\mathrm{HU})$; arrears decrease by $0.4 \%$ on average (SK, AT) to by $2.6 \%$ (HU). Even the indicator crime, violence or vandalism decrease by $0.3 \%$ on average (PL) to by $1.7 \%$ (SK). The indicator recorded theft has a declining character. With an overall view of economic oriented indicators, we can state that there is $75 \%$ of statistically confirmed cases, which represents a substantial part. However, up to 5 out of 8 analyzed indicators in the Slovak Republic were not statistically confirmed. 
Table 3. Employment indicators

\begin{tabular}{|c|c|c|c|c|c|c|c|c|c|c|}
\hline Indicators & & & & & & $\mathrm{L}$ & & $\mathrm{U}$ & AT & \\
\hline & $\begin{array}{c}\text { p-level } \\
\beta_{0}\end{array}$ & $\begin{array}{l}\mathrm{r} \\
\beta_{1}\end{array}$ & $\begin{array}{c}\text { p-level } \\
\beta_{0}\end{array}$ & $\begin{array}{c}\mathrm{r} \\
\beta_{1}\end{array}$ & $\begin{array}{c}\mathrm{p}- \\
\text { level } \\
\beta_{0}\end{array}$ & $\begin{array}{c}\mathrm{r} \\
\beta_{1}\end{array}$ & $\begin{array}{c}\mathrm{p}- \\
\text { level } \\
\beta_{0}\end{array}$ & $\begin{array}{c}\mathrm{r} \\
\beta_{1}\end{array}$ & $\begin{array}{c}\mathrm{p}- \\
\text { level } \\
\beta_{0}\end{array}$ & $\begin{array}{c}\mathrm{r} \\
\beta_{1}\end{array}$ \\
\hline $\begin{array}{l}\text { Unemployment } \\
\text { rates }\end{array}$ & $\begin{array}{l}.009 \\
66.6\end{array}$ & $\begin{array}{c}-.77 \\
-.0027\end{array}$ & $\begin{array}{l}.000 \\
22.9\end{array}$ & $\begin{array}{c}-.99 \\
-.0007\end{array}$ & $\begin{array}{l}.000 \\
29.8\end{array}$ & $\begin{array}{c}-.95 \\
-.0012\end{array}$ & $\begin{array}{l}.000 \\
35.3\end{array}$ & $\begin{array}{c}-.94 \\
-.0015\end{array}$ & $\begin{array}{l}.839 \\
4.6\end{array}$ & $\begin{array}{c}.07 \\
.0001\end{array}$ \\
\hline $\begin{array}{l}\text { Long-term } \\
\text { unemployment }\end{array}$ & $\begin{array}{l}.020 \\
46.0\end{array}$ & $\begin{array}{c}-.72 \\
-.0019 \\
\end{array}$ & $\begin{array}{l}.000 \\
10.4\end{array}$ & $\begin{array}{c}-.97 \\
-.0003 \\
\end{array}$ & $\begin{array}{l}.001 \\
12.6\end{array}$ & $\begin{array}{c}.86 \\
-.0005\end{array}$ & $\begin{array}{l}.000 \\
18.3\end{array}$ & $\begin{array}{c}-.96 \\
-.0008\end{array}$ & $\begin{array}{c}.454 \\
.3\end{array}$ & $\begin{array}{c}.27 \\
.0000\end{array}$ \\
\hline $\begin{array}{l}\text { People with } \\
\text { very low work } \\
\text { intensity* }\end{array}$ & $\begin{array}{l}.190 \\
21.2\end{array}$ & $\begin{array}{c}-.56 \\
-.0007\end{array}$ & $\begin{array}{l}.021 \\
14.1\end{array}$ & $\begin{array}{c}-.78 \\
-.0003\end{array}$ & $\begin{array}{l}.004 \\
13.2\end{array}$ & $\begin{array}{c}-.88 \\
-.0004\end{array}$ & $\begin{array}{l}.003 \\
46.2\end{array}$ & $\begin{array}{c}-.95 \\
-.0019\end{array}$ & $\begin{array}{l}.258 \\
13.2\end{array}$ & $\begin{array}{c}-.45 \\
-.0001\end{array}$ \\
\hline $\begin{array}{l}\text { Average } \\
\text { number of usual } \\
\text { weekly hours of } \\
\text { work }\end{array}$ & $\begin{array}{l}.034 \\
45.3\end{array}$ & $\begin{array}{c}-.67 \\
-.0002\end{array}$ & $\begin{array}{l}.000 \\
43.8\end{array}$ & $\begin{array}{c}-.90 \\
-.0001\end{array}$ & $\begin{array}{l}.037 \\
41.4\end{array}$ & $\begin{array}{c}-.66 \\
-.0000\end{array}$ & $\begin{array}{l}.681 \\
39.4\end{array}$ & $\begin{array}{c}.15 \\
.0000\end{array}$ & $\begin{array}{l}.001 \\
44.1\end{array}$ & $\begin{array}{c}-.89 \\
-.0002\end{array}$ \\
\hline $\begin{array}{l}\text { Employed } \\
\text { persons working } \\
\text { on Saturdays }\end{array}$ & $\begin{array}{r}\mathbf{0 3 4} \\
48.3\end{array}$ & $\begin{array}{c}-.67 \\
-.0012\end{array}$ & $\begin{array}{l}.000 \\
36.0\end{array}$ & $\begin{array}{c}-.93 \\
-.0007\end{array}$ & $\begin{array}{l}.000 \\
29.9\end{array}$ & $\begin{array}{c}-.98 \\
-.0008\end{array}$ & $\begin{array}{l}.000 \\
21.8\end{array}$ & $\begin{array}{c}-.94 \\
-.0006\end{array}$ & $\begin{array}{l}.000 \\
46.3\end{array}$ & $\begin{array}{c}-.97 \\
-.0005\end{array}$ \\
\hline $\begin{array}{l}\text { Employed } \\
\text { persons working } \\
\text { on Sundays } \\
\end{array}$ & $\begin{array}{l}.148 \\
32.4\end{array}$ & $\begin{array}{c}-.49 \\
-.0007\end{array}$ & $\begin{array}{l}.001 \\
21.0\end{array}$ & $\begin{array}{c}-.87 \\
-.0003\end{array}$ & $\begin{array}{r}.000 \\
15.7\end{array}$ & $\begin{array}{c}-.96 \\
-.0005\end{array}$ & $\begin{array}{l}.002 \\
15.3\end{array}$ & $\begin{array}{c}-.84 \\
-.0004\end{array}$ & $\begin{array}{l}.000 \\
21.7\end{array}$ & $\begin{array}{c}-.95 \\
-.0002\end{array}$ \\
\hline $\begin{array}{l}\text { Inactive } \\
\text { population }\end{array}$ & $\begin{array}{l}.001 \\
57.7\end{array}$ & $\begin{array}{c}.86 \\
-.0014\end{array}$ & $\begin{array}{l}.000 \\
46.1\end{array}$ & $\begin{array}{c}-.96 \\
-.0008\end{array}$ & $\begin{array}{l}\mathbf{0 0 0} \\
47.6 \\
\end{array}$ & $\begin{array}{c}-.98 \\
-.0008\end{array}$ & $\begin{array}{l}.000 \\
67.7\end{array}$ & $\begin{array}{c}-.95 \\
-.0019\end{array}$ & $\begin{array}{l}.000 \\
37.6 \\
\end{array}$ & $\begin{array}{c}-.99 \\
-.0004\end{array}$ \\
\hline
\end{tabular}

Notes: *available data 2011-2019; data highlighted in bold indicate statistic dependence between variables.

Source: own compilation

Table 3 shows the results of regression analysis of employment-oriented indicators. In most cases within this category only negative statistical dependence was demonstrated. In other words, when the GDP of a country improves by one thousand PPS units, the value of the given indicator decreases. These analyzed indicators are: unemployment rate decreases by $0.7 \%$ on average $(\mathrm{CZ})$ to by $2.7 \%(\mathrm{SK})$; in the case of the long-term unemployment the development is similar; indicator of people living in household with very low work intensity decreases by $0.3 \%$ on average (CZ) to by $1.9 \%$ (HU); inactive population indicator decreases by $0.4 \%$ on average (AT) to by $1.9 \%$ (HU). In total, $83 \%$ of cases were statistically confirmed.

Table 4. Health oriented indicators

\begin{tabular}{|c|c|c|c|c|c|c|c|c|c|c|}
\hline Indicators & & & & & & & & & AT & \\
\hline & $\begin{array}{c}\text { p-level } \\
\beta_{0}\end{array}$ & $\begin{array}{c}\mathrm{r} \\
\beta_{1}\end{array}$ & $\begin{array}{c}\text { p-level } \\
\beta_{0}\end{array}$ & $\begin{array}{c}\mathrm{r} \\
\beta_{1}\end{array}$ & $\begin{array}{c}\text { p-level } \\
\beta_{0}\end{array}$ & $\begin{array}{l}\mathrm{r} \\
\beta_{1}\end{array}$ & $\begin{array}{c}\text { p-level } \\
\beta_{0}\end{array}$ & $\begin{array}{l}\mathrm{r} \\
\beta_{1}\end{array}$ & $\begin{array}{c}\text { p-level } \\
\beta_{0}\end{array}$ & $\begin{array}{c}\mathrm{r} \\
\beta_{1}\end{array}$ \\
\hline $\begin{array}{l}\text { Life } \\
\text { expectancy* }\end{array}$ & $\begin{array}{l}.076 \\
66.9 \\
\end{array}$ & $\begin{array}{c}.71 \\
.0005 \\
\end{array}$ & $\begin{array}{l}.272 \\
-25.6 \\
\end{array}$ & $\begin{array}{c}.44 \\
.0040 \\
\end{array}$ & $\begin{array}{l}\mathbf{0 3 4} \\
73.5 \\
\end{array}$ & $\begin{array}{c}.75 \\
.0002 \\
\end{array}$ & $\begin{array}{l}\mathbf{. 0 4 3} \\
72.1 \\
\end{array}$ & $\begin{array}{c}.83 \\
.0002 \\
\end{array}$ & $\begin{array}{l}.008 \\
76.4 \\
\end{array}$ & $\begin{array}{c}.85 \\
.0001 \\
\end{array}$ \\
\hline $\begin{array}{l}\text { Healthy life } \\
\text { years }\end{array}$ & $\begin{array}{l}.049 \\
22.1\end{array}$ & $\begin{array}{c}.76 \\
.0016\end{array}$ & $\begin{array}{l}.176 \\
67.1\end{array}$ & $\begin{array}{c}.53 \\
-.0002\end{array}$ & $\begin{array}{l}\mathbf{0 1 6} \\
55.1\end{array}$ & $\begin{array}{c}.80 \\
.0004\end{array}$ & \begin{tabular}{|l}
$\mathbf{0 3 3}$ \\
52.2
\end{tabular} & $\begin{array}{c}.85 \\
.0004\end{array}$ & \begin{tabular}{|l|}
.018 \\
85.1
\end{tabular} & $\begin{array}{c}-.80 \\
-.0007\end{array}$ \\
\hline $\begin{array}{l}\text { Self- } \\
\text { perceived } \\
\text { health } \\
\end{array}$ & $\begin{array}{l}.610 \\
16.8\end{array}$ & $\begin{array}{c}.18 \\
.0002\end{array}$ & $\begin{array}{l}.529 \\
17.7\end{array}$ & $\begin{array}{c}.23 \\
.0001\end{array}$ & $\begin{array}{l}.000 \\
25.6\end{array}$ & $\begin{array}{c}-.94 \\
-.0005\end{array}$ & $\begin{array}{l}.523 \\
14.8\end{array}$ & $\begin{array}{c}.23 \\
.0001\end{array}$ & $\begin{array}{l}.913 \\
31.6\end{array}$ & $\begin{array}{c}.04 \\
.0000\end{array}$ \\
\hline $\begin{array}{l}\text { Self-reported } \\
\text { unmet needs } \\
\text { for medical }\end{array}$ & $\begin{array}{l}.064 \\
-1.5\end{array}$ & $\begin{array}{c}.61 \\
.0001\end{array}$ & $\begin{array}{l}.919 \\
.08\end{array}$ & $\begin{array}{c}.04 \\
.0000\end{array}$ & $\begin{array}{l}.492 \\
1.2\end{array}$ & $\begin{array}{l}-.25 \\
.0000\end{array}$ & $\begin{array}{c}. \mathbf{0 3 0} \\
2.0\end{array}$ & $\begin{array}{c}-.68 \\
-.0000\end{array}$ & $\begin{array}{c}.553 \\
.7\end{array}$ & $\begin{array}{l}-.21 \\
-.0000\end{array}$ \\
\hline
\end{tabular}

Notes: *available data 2010-2018; data highlighted in bold indicate statistic dependence between variables.

Source: own compilation 
In the health-oriented category 4 indicators were analyzed (Table 4). Positive statistical dependence was confirmed in the case of the life expectancy indicator (except SK), whereby with the improvement of a country's GDP by a thousand units of PPS, the life expectancy in countries increases by two months on average (PL, HU, AT). In addition, positive statistical dependence can be observed within the indicator of healthy life years. In the indicator of self-perceived health the statistical dependence was proven only in the case of Poland (p-level =.000), and we can state that increasing the GDP level by a thousand units of PPS this indicator decreases by $0.4 \%$ on average. This is mostly a subjective indicator, which represents the inhabitant's perception of health in the status of very good. Analogical, within the indictor of self-reported unmet needs for medical examination only one case indicated statistical dependence (HU, p-level=.030). According to the correlation coefficient $(r=-68)$ the moderate significant statistical dependence can be stated. It means that with GDP growth by one thousand PPS units, the percentage of self-reported unmet needs for medical examination decreases by $0.007 \%$ on average (HU). In total from the given category only $45 \%$ of cases are statistically confirmed.

Table 5. Education oriented indicators

\begin{tabular}{lccccccccccc}
\hline Indicators & \multicolumn{2}{c}{$\mathrm{SK}$} & \multicolumn{2}{c}{$\mathrm{CZ}$} & \multicolumn{2}{c}{$\mathrm{PL}$} & \multicolumn{2}{c}{$\mathrm{HU}$} & \multicolumn{2}{c}{$\mathrm{AT}$} \\
\hline & $\mathrm{p}-$ level & $\mathrm{r}$ & $\mathrm{p}-$ level & $\mathrm{r}$ & $\mathrm{p}-$ level & $\mathrm{r}$ & $\mathrm{p}-$ level & $\mathrm{r}$ & $\mathrm{p}$-level & $\mathrm{r}$ \\
& $\beta_{0}$ & $\beta_{1}$ & $\beta_{0}$ & $\beta_{1}$ & $\beta_{0}$ & $\beta_{1}$ & $\beta_{0}$ & $\beta_{1}$ & $\beta_{0}$ & $\beta_{1}$ \\
\hline $\begin{array}{l}\text { Educational } \\
\text { level - upper } \\
\text { secondary }\end{array}$ & $\mathbf{. 0 0 2}$ & -.84 & $\mathbf{. 0 0 0}$ & -.96 & $\mathbf{. 0 0 0}$ & -.98 & .699 & -.14 & $\mathbf{. 0 0 2}$ & -.85 \\
\hline $\begin{array}{l}\text { Educational } \\
\text { level }-\end{array}$ & $\mathbf{. 0 0 1}$ & .89 & $\mathbf{. 0 0 0}$ & .92 & $\mathbf{. 0 0 0}$ & .98 & $\mathbf{. 0 0 0}$ & .94 & $\mathbf{. 0 0 0}$ & .88 \\
tertiary & -29.7 & .0024 & -1.3 & .0008 & -1.0 & .0013 & -5.8 & .0008 & -61.4 & .0024 \\
\hline $\begin{array}{l}\text { Participation } \\
\text { rate in }\end{array}$ & $\mathbf{. 0 1 2}$ & -.75 & $\mathbf{. 0 1 2}$ & -.73 & $\mathbf{. 0 1 2}$ & -.75 & .171 & .47 & .064 & .60 \\
education & 24.1 & - & 25.9 & -.0004 & 19.5 & -.0004 & 6.3 & .0003 & 13.1 & .0002 \\
\hline
\end{tabular}

Note: data highlighted in bold indicate statistic dependence between variables.

Source: own compilation

Based on the results presented in Table 5, positive statistical dependence is declared only in the case of tertiary level of education in all V4 countries. We can state that with an increase of GDP by one thousand PPS units, this indicator increases in individual countries by $0.8 \%$ on average (HU) to by $2.4 \%$ (SK, AT). Since 2010, the indicator has had a growing trend each year in all analyzed countries. In 2019, the most represented percentage of tertiary education from population is in Austria, Poland, and the Slovak Republic. On the contrary, the negative statistical dependence is indicated within indicator of educational level - upper secondary (non-tertiary) and participation in education and training. If the GDP value grows by one thousand units of PPS, these indicators decrease by about $1.18 \%$ on average (the secondary education) and $0.4 \%$ (the participation rate in education). Overall $80 \%$ of analyzed cases were confirmed.

Table 6 shows the results related to the gender gap. In this category only $50 \%$ cases of dependence of the analyzed variables were confirmed. The statistical dependence was confirmed in all countries except the Slovak Republic (in one case PL and HU). However, we can state that with the increase of GDP value, the gender employment gap decreases by $0.2 \%$ on average (AT) $-0.8 \%$ (HU), and gender pay gap decreases by $0.4 \%$ on average (CZ) $0.6 \%$ (AT). 
Table 6. Gender equality-oriented indicators

\begin{tabular}{lcccccccccc}
\hline Indicators & \multicolumn{2}{c}{$\mathrm{SK}$} & \multicolumn{2}{c}{$\mathrm{CZ}$} & \multicolumn{2}{c}{$\mathrm{PL}$} & $\mathrm{HU}$ & \multicolumn{2}{c}{$\mathrm{AT}$} \\
\hline & $\mathrm{p}-$-level & $\mathrm{r}$ & $\mathrm{p}$-level & $\mathrm{r}$ & $\mathrm{p}-$ level & $\mathrm{r}$ & $\mathrm{p}$-level & $\mathrm{r}$ & $\mathrm{p}$-level & $\mathrm{r}$ \\
& $\beta_{0}$ & $\beta_{1}$ & $\beta_{0}$ & $\beta_{1}$ & $\beta_{0}$ & $\beta_{1}$ & $\beta_{0}$ & $\beta_{1}$ & $\beta_{0}$ & $\beta_{1}$ \\
\hline $\begin{array}{l}\text { Gender } \\
\text { employment }\end{array}$ & .093 & -.56 & $\mathbf{. 0 0 0}$ & -.97 & .132 & .51 & $\mathbf{. 0 0 0}$ & .95 & .058 & -.62 \\
gap & 24.7 & -.0005 & 27.4 & -.0004 & 12.5 & .0001 & -1.8 & .0008 & 42.1 & -.0002 \\
\hline $\begin{array}{l}\text { Gender pay } \\
\text { gap }\end{array}$ & .252 & -.40 & $\mathbf{. 0 0 2}$ & -.85 & $\mathbf{. 0 0 2}$ & -.85 & .266 & -.39 & $\mathbf{. 0 0 0}$ & -.98 \\
\hline
\end{tabular}

Note: data highlighted in bold indicate statistic dependence between variables.

Source: own compilation

Table 7. Natural and living oriented indicators

\begin{tabular}{|c|c|c|c|c|c|c|c|c|c|c|}
\hline Indicators & & & $\mathrm{C}$ & & & & $\mathrm{H}$ & & AT & \\
\hline & $\begin{array}{c}\mathrm{p} \text {-level } \\
\beta_{0}\end{array}$ & $\begin{array}{c}\mathrm{r} \\
\beta_{1}\end{array}$ & $\begin{array}{c}\text { p-level } \\
\beta_{0}\end{array}$ & $\begin{array}{c}\mathrm{r} \\
\beta_{1}\end{array}$ & $\begin{array}{c}\text { p-level } \\
\beta_{0}\end{array}$ & $\begin{array}{c}\mathrm{r} \\
\beta_{1}\end{array}$ & $\begin{array}{c}\text { p-level } \\
\beta_{0}\end{array}$ & $\begin{array}{l}\mathrm{r} \\
\beta_{1}\end{array}$ & $\begin{array}{c}\text { p-level } \\
\beta_{0}\end{array}$ & $\begin{array}{c}\mathrm{r} \\
\beta_{1}\end{array}$ \\
\hline $\begin{array}{l}\text { Exposure to } \\
\text { air } \\
\text { pollution* }\end{array}$ & $\begin{array}{c}.049 \\
102.9\end{array}$ & $\begin{array}{c}-.76 \\
-.0041\end{array}$ & $\begin{array}{l}.245 \\
24.6\end{array}$ & $\begin{array}{c}-.47 \\
-.0002\end{array}$ & $\begin{array}{l}.018 \\
39.8\end{array}$ & $\begin{array}{c}-.80 \\
-.0008\end{array}$ & $\begin{array}{l}.234 \\
41.4\end{array}$ & $\begin{array}{c}-.57 \\
-.0011\end{array}$ & $\begin{array}{l}.065 \\
41.1\end{array}$ & $\begin{array}{c}-.68 \\
-.0007\end{array}$ \\
\hline $\begin{array}{l}\text { Pollution, } \\
\text { other enviro } \\
\text { problems }\end{array}$ & $\begin{array}{l}.001 \\
85.7\end{array}$ & $\begin{array}{c}-.91 \\
-.0035\end{array}$ & $\begin{array}{l}.000 \\
34.6\end{array}$ & $\begin{array}{c}-.93 \\
-.0008\end{array}$ & $\begin{array}{l}.001 \\
-.14\end{array}$ & $\begin{array}{c}.88 \\
.0006\end{array}$ & $\begin{array}{l}.667 \\
15.1\end{array}$ & $\begin{array}{c}-.16 \\
-.0001\end{array}$ & $\begin{array}{l}.975 \\
-.0\end{array}$ & $\begin{array}{c}-.01 \\
-.0000\end{array}$ \\
\hline
\end{tabular}

Notes: *unavailable data SK (2013); HU (2015, 2016); data highlighted in bold indicate statistic dependence between variables.

Source: own compilation

The last category of analyzed indicators represents the natural and living oriented indicators (Table 7). In both cases, the statistical dependence is negative. As in the previous case, only $50 \%$ of cases were confirmed in total. It can be stated that with the increase of GDP by thousand PPS units, the value of indicator of pollution, grime or other environmental problems decreases by $0.8 \%$ on average $(\mathrm{CZ})$ to by $3.5 \%(\mathrm{SK})$. In the case of Poland, there is a positive statistical dependence, with a high strength $(r=0.88)$, which means that with the increase of GDP, this indicator grows by $0.6 \%$ on average. By statistical analysis a negative statistical dependence in the indicator of the exposure to air pollution was confirmed. The cases of the Slovak Republic (margin level of $p$-value $=0.049)$ and Poland (p-level $=0.018$ ) signify that the growth of GDP value decreases this indicator by 0.7 on average (PL) to by 4.1(SK) particulates $<2.5 \mu \mathrm{m}$.

\section{Discussion and conclusion}

Our research results show (Graph 3) that value of GDP measured in PPS per capita in Austria is still (even more than 30 years after the change to a market economy) much higher than in the V4 countries. These results can be considered unsatisfactory from the point of view of the V4 countries comparing to Austria as a benchmark country. Among the V4 countries, the Czech Republic has the highest value of GDP. Currently, the lowest economic level is reached by the Slovak Republic (2019). Nevertheless, a positive fact is that in the last 10 years (2010-2019) the trend of GDP development was growing in all 4 monitored V4 countries (except Slovakia in the year of 2016). On other hand, this growth cannot be considered sufficient while the gap in GDP comparing to Austria still remains. Only in the case of the Czech Republic the GDP gap comparing to Austria decreased slightly from 10,800 in PPS (year 2010) to 10,500 in PPS (year 2019). In other V4 countries, even this gap increased during the monitored period. 
Moreover, within the V4 countries (especially SK, CZ, HU), the automotive industry has a key position in the GDP creation, which is based on a significant inflow of FDI (foreign direct investment) into this industry in the last 3 decades. For many years, Slovakia has been the largest producer of passenger cars worldwide (dominant brands are VW, Peugeot and Citroen, KIA and in recent years also Jaguar and dozens of companies as subcontractors of automotive components) at the level of production of more than 200 cars/ 1 inhabitant in 2019 (note: $\mathrm{CZ}$ reaches about 1.5 times and $\mathrm{HU}$ up to about 4 times lower value; source: https://www.oica.net). This strategic position of the automotive industry in Slovakia in a combination with the time shifting (compared to the other V4 countries) of a significant inflow of FDI into this sector while the positive effect of these previous FDIs is still running could be crucial reason why Slovakia has maintained the GDP growth in comparable to other V4 countries. Another key reason could be the fact that Slovakia recorded an extremely high increase of General Government gross debt in the period 2008-2019, which is expressed in percentage of GDP. This value is up to the level of $+19.4 \%$ increase in indebtedness in this period (own calculation; source of data: Eurostat). Unlike Slovakia, the Czech Republic $(+2.5 \%)$ and Austria $(+1,7 \%)$ recorded only a slight increase in debt and even Poland reduced its debt by $0.7 \%$ and $\mathrm{HU}$ by as much as $5.5 \%$.

From this point of view, and current situation with the Covid-19 pandemic, the above mentioned appears to be a major risk for the future. It is possible that the Covid-19 pandemic will create enormous pressures on further government indebtedness, whereas mainly the Slovak Republic exhausted this possibility in this view in the past. Another significant risk for the future is the already mentioned dominant position of the automotive industry in case of Slovakia. In recent years, this sector has been going through a turning point in the EU's industrial policy negotiations. However, soon, countries need to respond to moving to a lowcarbon economy, reduce emissions and the share of industrial production in the overall economy of the EU countries. This sector thus faces new challenges, such as electro-mobility and the use of an alternative fuels (Ministry of Economy of the Slovak Republic, 2019). Furthermore, if we consider also the emerging digitization, robotics and the phenomenon of Industry 4.0, which will significantly limit traditional jobs in the automotive industry, the combination of all the above mentioned factors, especially in the Slovak Republic, seems fatal. This situation is also appertaining to the soft indicators, which certainly include the life quality and well-being of inhabitants.

Within the main research hypothesis, it could be stated that the economic performance measured through GDP had a really positive effect on indicators of life quality in most of cases monitored. Based on this, in general we agree with Cann who claims that growth can cause growth income and improving of well-being (Cann, 2017). In total approx. 2/3 (69\%) of all cases observed related to main research hypothesis were statistically confirmed. From these the GDP growth in the V4 countries and Austria in period 2010-2019 had a really positive effect on the improvement of the life quality in more than half $(61.5 \%)$ of the analyzed indicators (in total 130 cases were observed). From the result of our research the impact of GDP on analyzed life quality indicators cannot be denied. In comparison with Austria as a benchmark country we can state that all V4 countries (except Slovakia) achieved better development in the analyzed period. Therefore, this development in the V4 countries over the last 10 monitored years can be described as more positive than in Austria. The Slovak Republic and Austria reached the least confirmed really positive cases of statistical dependence (AT 53.8\%; SK even only 50\%). In contrast, PL reached the most confirmed cases of analyzed indicators (73.1\%), followed by CZ (69.2\%) and HU (61.5\%). On the other hand, we should state that despite the positive development trend in 2010-2019 in most of the V4 countries comparing to Austria, this is not strong enough. In most of the monitored life quality indicators Austria still achieves their better absolute values (see Graphs 1, 2). 
However, in most of life quality indicators, the level of the V4 countries is better or the same (inactive population, inability to make ends need) than the EU 27 average. These results are fully contrary to the research presented by Androniceanu et al. (2018) in Romania and shown a continued economic growth over the last five years (the largest economic growth in the EU in 2017). However, the quality of life in Romania has not improved properly. Our results are also fully inconsistent with a study conducted by Chisadza and Loots (2019) in the conditions of Africa.

In general, based on our research results we agree that the sustainable economic development is a concept with a wide range of areas and indicators which are focused not only on economic outcomes (Corrigan et al., 2014). Conformably to Cann (2017), there are so many other factors which are important to overall well-being, e.g., environmental, or social topics which can play a determining economic success in the future. However, policy makers should consider these evaluations as well as the results of our research at least as a starting point in the field of improving sustainable economic development and well-being of countries' inhabitants. Moreover, it is also necessary to focus more on increasing the living standards (the quality of life). Suggestion that the issue of the life quality perspective will be (it has not yet been considered) sufficiently and systematically considered, in our view, would be a step towards the sustainable development as well as the sustainable economic development. We agree with the statement of author Cann (2017), that productivity leads to growth, which can cause income growth and improving of well-being. Based on our research framework and research results we can also state that the V4 countries are on the track to fulfill this statement because of the previous 10-year development was going in a positive direction. Nevertheless, when compared to Austria as a highly developed country, a significant gap can still be observed. The reason is that this positive trend is not sufficiently strong to catch up with Austria in this area of social aspects oriented sustainable economic development. Therefore, in this part of the research, we agree with the statement of authors Despotovic et al. (2019), that the post-transition European countries have a lower level of sustainable competitiveness development even in social area.

In the future our research goal is to continue in this direction with elimination of some current limitations. Examples are: the inclusion of more than five CE countries, the addition of more environmental indicators in terms of meeting the general objectives of sustainable development while using the alternative indicator of economic well-being. As a further limitation of the research we can also mention only the use of GDP as an indicator of economic growth.

The position of V4 countries in the global environment can be improved by conceptual and strategic decisions carried out by individual states. On the other hand, it is necessary to understand that the corporate sector and individuals should also participate in this issue. However, the state policy makers play a key role in creating the conditions for future development. Because of countries with similar starting conditions, as well as a quality business environment, the creating conditions for long-term sustainable economic growth including social aspects and quality of life are a basic prerequisite for business development and increasing the competitiveness of the country's economy internationally.

\section{Acknowledgement}

This paper is the partial result of the GAAA - Grantová agentura Akademické alliance grant project No. GA/6/2019 - Strategic Performance Management of Companies and Multinational Corporations in the Context of Globalization and Sustainability. 


\section{References}

Androniceanu, A., Dragulanescu, I., \& Mioara Duca (2018). Economic Growth and Quality of Life in Romania. In Soliman, KS ed.: Innovation management and education excellence through vision 2020, 31st International-Business-Information-ManagementAssociation Conference, Milan, 1862-1870.

Appiah, E. N. (2017). The effect of education expenditure on per capita GDP in developing countries. International Journal of Economics and Finance, 9(10), 136-144. doi:10.5539/ijef.v9n10p136

Caballero-Morales, S.O., Cordero-Guridi, J.J., Alvarez-Tamayo, R.I., \& Cuautle-Gutiérrez, L. (2020). Education 4.0 to Support Entrepreneurship, Social Development and Education in Emerging Economies. International Journal of Entrepreneurial Knowledge, 8(2), 89100. doi: 10.37335/ijek.v8i2.119

Cann, O. (2017). What exactly is economic competitiveness? https://www.weforum.org/agenda/2017/09/what-is-economic-competitiveness/

Corrigan, G., Crotti, R., Hanouz, M. D., \& Serin, C. (2014). Assessing progress toward sustainable competitiveness. In Schwab, K., 2014. Global competitiveness report 20142015. http://www3.weforum.org/docs/WEF_GlobalCompetitivenessReport_201415.pdf

Čepel, M. (2019). Social and Cultural Factors and Their Impact On The Quality Of Business Environment In the SME Segment. International Journal of Entrepreneurial Knowledge, 7(1), 65-73. doi: 10.37335/ijek.v7i1.88

De Carvalho, Í.C.S., Di Serio, L.C., Guimarães, C.M.C., \& Furlanetto, K.S. (2020). The social progress on the development of global competitiveness. Competitiveness Review, (Early access), https://doi.org/10.1108/CR-12-2018-0078

Despotovic, D., Cvetanovic, S., Nedic, V., \& Despotovic, M. (2019). Social aspects of sustainable competitiveness in the selected European countries in the period 2012-2015. Social Indicators Research, 141, 841-860. doi: 10.1007/s11205-018-1840-4

Ekici, Ş. Ö., Kabak, Ö., \& Ülengin, F. (2019). Improving logistics performance by reforming the pillars of global competitiveness index. Transport Policy, 81, 197-207. doi: 10.1016/j.tranpol.2019.06.014

Elistia, E., \& Syahzuni, B. A. (2018). The correlation of the human development index towards economic growth (GDP per capita) in 10 ASEAN member countries. Journal of Humanities and Social Studies, 2(2), 40-46. doi: 10.33751/jhss.v2i2.949

European Central Bank. https://www.ecb.europa.eu/pub/economicbulletin/articles/2020/html/ecb.ebart202007_01 ef0a77a516.en.html

European Commission. (2009). Sustainable development in the European Union. 2009 monitoring report of the EU sustainable development strategy. https://ec.europa.eu/eurostat/documents/3217494/5703739/KS-78-09-865-

EN.PDF/7ccc9240-03ae-40da-b2d8-2cc8a28df320

Eurostat, (a). Quality of life indicators. https://ec.europa.eu/eurostat/web/quality-oflife/data/database?p_p_id=NavTreeportletprod_WAR_NavTreeportletprod_INSTANC E_6C6Bg4FCUXTD\&p_p_lifecycle=0\&p_p_state=normal\&p_p_mode=view

Eurostat, (b). Purchasing power adjusted GDP per capita. https://ec.europa.eu/eurostat/databrowser/view/sdg_10_10/default/table?lang=en

Eurostat, (c). Mean and median income by age and sex. https://ec.europa.eu/eurostat/databrowser/view/ilc_di03\$DV_405/default/table?lang=en

Eurostat, (d). Exposure to air pollution by particulate matter. https://ec.europa.eu/eurostat/databrowser/view/sdg_11_50/default/table?lang=en 
Fan, Q., Goetz, S. J., \& Liang, J. (2016). The interactive effects of human capital and quality of life on economic growth. Applied Economics, 48(53), 5186-5200. doi: 10.1080/00036846.2016.1173180

Gavurová, B., Ivanková, V., Rigelský, M., \& Př́varová, M. (2020). Relations Between Tourism Spending and Global Competitiveness - an Empirical Study in Developed OECD Countries. Journal of Tourism and Services, 21(11), 38-54. doi: 10.29036/jots.v11i21.175

Giacalone, M., Mattera, R., \& Cusatelli, C. (2018). Do sustainable well-being indicators affect GDP? Evidence from a longitudinal study in Italy based on BES approach. Rivista Italiana di Economia Demografia e Statistica, 72(3), 125-148.

Grishin, V. I., Ustyuzhanina, E. V., \& Komarova, I. P. (2019). Main problems with calculating GDP as an indicator of economic health of the country. International Journal of Civil Engineering and Technology, 10(2), 1696-1703.

Hammer, J. \& Pivo, G. (2016). The triple bottom line and sustainable economic development theory and practice. Economic Development Quarterly, 31(1), 25-36 1-12. doi: $10.1177 / 0891242416674808$

Hill, T. D., Jorgenson, A. K., Ore, P. Balistreri, K. S., \& Clark, B. (2019). Air quality and life expectancy in the United States: An analysis of the moderating effect of income inequality. SSM - Population Health, 7. doi: 10.1016/j.ssmph.2018.100346

Chaabouni, S. \& Saidi, K. (2017). The dynamic links between carbon dioxide $\left(\mathrm{CO}_{2}\right)$ emissions, health spending and GDP growth: A case study for 51 countries. Environmental Research, 158, 137-144. doi: 10.1016/j.envres.2017.05.041

Chisadza, C. \& Loots, E. (2019). Economic Growth and Quality of Life in Africa. In Handbook of Quality of Life in African Societies (pp. 131-147). Springer, Cham.

IMD World Competitiveness Center. Global competitiveness report. https://www.imd.org/wcc/world-competitiveness-reflections/global-competitivenessreport/

Ivanová, E., \& Masárová, J. (2018). Performance evaluation of the Visegrad Group countries. Economic Research-Ekonomska Istraživanja, 31(1), 270-289. doi:10.10ä280/1331677X.2018.1429944

Juřičková, E., Pilik, M., \& Kwarteng, M. A. (2019). Efficiency measurement of national innovation systems of the european union countries: DEA model application. Journal of International Studies, 12(4), 286-299. doi: 10.14254/2071-8330.2019/12-4/19

Kalimeris, P., Bithas, K., Richardson, C., \& Nijkamp, P. (2020). Hidden linkages between resources and economy: A "Beyond-GDP" approach using alternative welfare indicators. Ecological Economic, 169. doi: 10.1016/j.ecolecon.2019.106508

Kim, H. S. (2017). Patterns of economic development: Correlations affecting economic growth and quality of life in 222 countries. Politics \& Policy, 45(1), 83-104. doi:10.1111/polp.12190

Kisel'áková, D., Šofranková, B., Čabinová, V., Onuferová, E., \& Šoltésová, J. (2018). The Impact of R\&D Expenditure on the Development of Global Competitiveness within the CEE EU Countries. Journal of Competitiveness, 10 (3), 34-50. doi:10.7441/joc.2018.03.03

Kwarciński, T., \& Ulman, P. (2020). Quality of life paradox. Well-being ranking of the selected European countries based on hybrid well-being approach. Economics and Sociology, 13(2), 160-180. doi:10.14254/2071-789X.2020/13-2/12

Maricic, M. (2019). Assessing the quality of life in the European Union: The European index of life satisfaction (EILS). Statistical Journal of the IASO, 35, 261-267.

Mason, R.D. \& Lind, D.A. (1990). Statistics: An introduction. Harcourt Publishers Ltd.

Ministry of Economy of the Slovak Republic (2019). 
Miola, A. \& Schiltz F. (2019). Measuring sustainable development goals performance: How to monitor policy action in the 2030 Agenda implementation?. Ecological Economics, 164, Article Number: 106373. doi: 10.1016/j.ecolecon.2019.106373

Nugraha, A. T., Prayitno, G., Situmorang, M. E., \& Nasution, A. (2020). The role of infrastructure in economic growth and income inequality in Indonesia. Economics and Sociology, 13(1), 102-115. doi:10.14254/2071-789X.2020/13-1/7

Popescu, G.H., Sima, V., Nica, E., \& Gheorghe, I.G. (2017). Measuring sustainable competitiveness in contemporary economies - insights from European economy. Sustainability, 9(7), 1230. doi: 10.3390/su9071230

Puglisi, S. \& Şerban, I. V. (2019). Beyond GDP: which options to better represent modern socio-economic progress? Sociology and Social Work Review, 3(1), 17-32.

Quiñonez Tapia, F., González-Betanzos, F., Vargas-Garduño, M. L., \& Aguirre Lozano, Z. E. (2020). Validation of the Social Entrepreneurial Antecedents Scale in University Students in Mexico. International Journal of Entrepreneurial Knowledge, 8(1), 1-18. doi: 10.37335/ijek.v8i2.97

Ranasinghe, R. \& Pradeepamali, J. (2019). Community Empowerment and their Support for Tourism Development: an Inquiry based on Resident Empowerment through Tourism Scale. Journal of Tourism and Services, 10(19), 55-76. doi: 10.29036/jots.v10i19.96

Ribeiro, S. \& Santos, A. (2019). The economics of happiness: An approach to Portuguese economy. Economics and Sociology, 12(4), 197-212. doi:10.14254/2071789X.2019/12-4/12

Roka, D. K. (2019). GDP growth and income paradoxical relation to happiness in China and South Asian countries. International Journal of Science and Business, 3(4), 61-85.

Schwab, K. (2019). The Global Competitiveness Report 2019. World Economic Forum. http://www3.weforum.org/docs/WEF_TheGlobalCompetitivenessReport2019.pdf

Stavytskyy, A., Kharlamova, G., Giedraitis, V., Cheberyako, O., \& Nikytenko, D. (2020). Gender question: Econometric answer. Economics and Sociology, 13(4), 241-255. doi:10.14254/2071-789X.2020/13-4/15

Stjepanović, S., Tomić, D., \& Škare, M. (2017). A new approach to measuring green GDP: A cross-country analysis. Entrepreneurship and Sustainability Issues, 4(4), 574-590. doi:10.9770/jesi.2017.4.4(13)

Stiglitz, J., Sen, A.K., \& Fitoussi, J.P. (2009). The measurement of economic performance and social progress revisited: Reflections and Overview. Hal-0106938, Paris: Centre de recherche en économie de Sciences Po. https://www.ofce.sciencespo.fr/pdf/dtravail/WP2009-33.pdf

Svenfelt, Å., Alfredsson, E. C., Bradley, K., Fauré, E., Finnveden, G., Fuehrer, P., Gunnarsson-Östling, U., Isaksson, K., Malmaeus, M., Malmqvist, T., Skånberg, K., Stigson, P., Aretun, Å., Buhr, K., Hagbert, P., \& Öhlund, E. (2019). Scenarios for sustainable futures beyond GDP growth 2050. Futures, 111, 1-14. doi:10.1016/j.futures.2019.05.001.

Uslu, A., Alagöz, G., \& Güneş, E. (2020). Socio-cultural, economic, and environmental effects of tourism from the point of view of the local community. Journal of Tourism and Services, 11(21), 1-21. doi: 10.29036/jots.v11i21.147

Vovk, I., Vovk, Y., \& Lyashuk, O. (2017). Improvement of the organizational-economic mechanism of resource-saving at the machine building enterprise. Economics, Management and Sustainability, 2(2), 6-14. doi:10.14254/jems.2017.2-2.1 